\title{
Genetic Variation and Relationship among Grain Yield and Yield Component Traits for Simultaneous Selection in Dry and Green Maize
}

\author{
G.O.S. Ojo1 , A. Odoba²
}

\author{
${ }^{1}$ Department of Crop Production, Federal University of Agriculture, P.M.B. 2373, Makurdi, NIGERIA. 970001. \\ ${ }^{2}$ National Cereals Research Institute, Badegi, NIGERIA.
}

\begin{abstract}
Field experiments were conducted in 2010 and 2011 to evaluate maize with the objective of determining genetic variation and relationship among yield and yield component traits for simultaneous selection in dry and green maize. Phenotypic variance was mainly accounted for by the genetic component. Heritability was high for flowering, height and ear traits and grain yield. All the traits were positively correlated with grain yield, with the ear traits of kernel rows/cob and kernels/row on cob contributing most to grain yield. The high heritability coupled with the highest genetic advance observed for kernels per row on cob, kernel rows/cob and grain yield at $20 \%$ selection intensity indicates that concentrating on these three traits in selection programme will achieve a fast progress in selection. Thus grain yield could be simultaneously selected with kernels per row on cob and kernel rows/cob for improvement in dry and green maize production.
\end{abstract}

Keywords: Genetic variation, Simultaneous selection

\section{INTRODUCTION}

Maize (Zea mays (L.)), also known as corn, is a very important food crop for man, feed for livestock and other products for the industry (Chen et al., 2012), and ranks third after wheat and rice in world production (Obi, 1991; Keskin et al., 2005; Wattoo et al., 2009). Maize is a major staple food crop in subSaharan Africa (Akinwale et al., 2013). The global production of maize is estimated to be about 300 million metric tons per year of which about 50\% (145 million metric tons) is produced in USA alone. Out of the 9 million ha of land cropped to maize in Africa, Nigeria alone occupied 1 million ha representing $6.5 \%$ of maize produced in Africa (Abdulrahaman and Kolawole, 2006). Maize is therefore a very important crop in Nigeria.

For the farmer, there is always an available market for maize. However the productivity of the maize variety available to the farmer determines his return on investment. There is therefore, the need for the cultivation of high yielding varieties of maize. The International Institute for Tropical Agriculture (IITA) had always been alive to its mandate in the breeding of field corn and has developed extra early, early, medium and late maturing high yielding open pollinated and hybrid varieties in Nigeria. These improved varieties are readily available to farmers via national research institutes, universities, seed companies and various agricultural agencies such as state government agricultural development project outlets.

Out of the total land area cultivated to maize (corn) in Nigeria, more than $90 \%$ is devoted to the production of field corn (dent, flint and flour maize) alone. Hence, field corn is used to not only produce dry grain for flour and other products, but also to substitute two other types of corn namely, pop corn and sweet corn as green maize. The consumption of green maize is very popular and constitutes one assured meal for the average Nigerian citizen (Fajemisin, 2014) during the corn growing season.

The ultimate objective of maize research and cultivation in Nigeria is to achieve high grain yield with little attention given to other traits even though they are simultaneously measured along with grain weight. In green maize production, ear characteristics such as ear length, ear diameter and more importantly, grain filling expressed as kernels/row on $\mathrm{cob}$ and kernel rows/cob determine the price paid for

This article is published under the terms of the Creative Commons Attribution License 4.0

Author(s) retain the copyright of this article. Publication rights with Alkhaer Publications.

Published at: http://www.ijsciences.com/pub/issue/2016-07/

DOI: $10.18483 /$ ijSci.935; Online ISSN: 2305-3925; Print ISSN: 2410-4477 
boiled and roasted corn in Nigeria. There is therefore the need to select not only for grain yield but also for other traits, particularly the ear traits towards satisfying consumers' demand for well filled cob. But there is dearth of information on genetic variability on these ear traits and how they relate and contribute to grain yield. Such information will guide the breeder in the selection programme in breeding for maize that will simultaneously satisfy the demand for high grain yield and green maize.

The current research was therefore initiated to determine genetic variation and relationship among grain yield and yield component traits for simultaneous selection in dry and green maize.

\section{MATERIALS AND METHODS \\ Location}

The experiment was conducted during the rain fed cropping seasons of 2010 and 2011at the Teaching and Research Farm of the Federal University of Agriculture Makurdi, Nigeria. Makurdi is located on latitude $07^{\circ} 41^{\prime} \mathrm{N}$ and longitude $08^{\circ} 37^{\prime} \mathrm{E}$, in the southern Guinea Savanna agro - ecological zone of Nigeria. Meteorological information for Makurdi is presented in Table 1 while the soil physical and chemical characteristics for the experimental sites are summarized in Table 2.

\section{Planting Materials}

A total of fifteen (15) varieties of maize, comprising one (1) hybrid variety and fourteen (14) open pollinated varieties. The hybrid is an IITA (International Institute for Tropical Agriculture) developed hybrid for Nigeria while the open pollinated varieties comprise ten (10) improved open pollinated varieties and four local varieties. The ten (10) open pollinated varieties (including composites and synthetics) are IITA improved varieties developed for Nigeria while the four (4) local varieties were sourced from parts of Benue and Kogi States in the southern Guinea Savanna ecological zone of Nigeria. All the improved varieties were sourced from IITA, Ibadan, Nigeria. Names of the varieties and sources are presented in Table 3.

\section{Experimental layout and cultural practices}

The experiments were laid out in a randomised complete block design and treatments were randomly assigned to plots measuring $3 \mathrm{~m}$ x $4 \mathrm{~m}$ (four ridges per plot) for each of the years. Three seeds were sown to designated plots on August 4 ${ }^{\text {th }}, 2010$ and June $2^{\text {nd }}$, 2011 , at an intra - row spacing of $0.50 \mathrm{~m}$ on ridges spaced $75 \mathrm{~cm}$ apart, but emerged seedlings were later thinned down to two stands per hill two weeks later.
Compound fertilizer NPK 15:15:15 was applied 2 weeks after planting, to supply $60 \mathrm{~kg} \mathrm{~N} / \mathrm{ha}, 60 \mathrm{~kg}$ $\mathrm{P}_{2} \mathrm{O}_{5} / \mathrm{ha}$ and $60 \mathrm{~kg} \mathrm{k}_{2} \mathrm{O} / \mathrm{ha}$. Hoe weeding was carried out at three weeks after planting and just before top dressing. All plots were top dressed with urea $(46 \%$ $\mathrm{N})$ at the rate of $60 \mathrm{kgN} / \mathrm{ha}$ at six weeks after planting.

\section{Data Collection and analysis}

Data collected in the course of the experiment include days to tasseling, days to anthesis, days to silking, anthesis - silking interval, plant height, ear height, ear length, kernel rows/cob, kernels/row on $\mathrm{cob}$ and grain yield. Plant and ear heights were measured at maturity while data on ear traits (ear length, kernel rows/cob and kernels/row on cob) were taken at both the green and dry stage. Data at the green stage was taken three weeks after silking from two outer rows in each plot.

Data generated from the two years experiments were subjected to analysis of variance by the General Linear Model (GLM) and the Analysis of variance (ANOVA) procedures of SAS (1990) while SPSS statistics 17 was used to correlate genotypic means of all the traits measured.

Components of variance were estimated according to Bliss et al. (1973). Variance components were obtained by equating the mean square for a source of variation to its expectation and solving for the unknown as given below:

$\boldsymbol{\delta}^{2}{ }_{\mathrm{e}}=\mathrm{M}_{3}$

$\boldsymbol{\delta}^{\mathbf{2}}$ ge $=\mathrm{M}_{2}-\mathrm{M}_{3} / \mathrm{r}$

$\boldsymbol{\delta}^{2} \mathrm{~g}=\mathrm{M}_{1}-\mathrm{M}_{2} / \mathrm{rt}$

Where: $\boldsymbol{\delta}^{\mathbf{2}}, \boldsymbol{\delta}^{\mathbf{2}}$ ge and $\boldsymbol{\delta}^{\mathbf{2}}$ gare components of variance for error, genotype by year interaction and genotype, respectively. $\mathrm{M}_{1}, \mathrm{M}_{2}$, and $\mathrm{M}_{3}$ are the observed values of the mean squares for the genotype, interaction and error, respectively (Fehr, 1987).

Broad sense heritability ( $\left.\mathbf{H}_{\mathbf{B S}}(\boldsymbol{\%})\right)$ was calculated as the ratio of the genotypic variance to phenotypic variance using the formula of Allard (1960): $\boldsymbol{\delta}^{\mathbf{2}} \mathrm{g} / \boldsymbol{\delta}^{\mathbf{2}}$ ph X 100

Where $\mathbf{H}_{\mathrm{BS}}=$ broad sense heritability $(\%), \boldsymbol{\delta}^{\mathbf{2}} \mathbf{g}=$ genotypic variance, $\boldsymbol{\delta}^{\mathbf{2}} \mathbf{p h}=$ phenotypic variance $\boldsymbol{\delta}^{\mathbf{2}}{ }_{\mathrm{ph}}=\boldsymbol{\delta}_{\mathrm{e}}^{\mathbf{2}}+\boldsymbol{\delta}_{\mathrm{ge}}^{\mathbf{2}}+\boldsymbol{\delta}^{\mathbf{2}}$ as defined by Fehr (1987). PCV (phenotypic coefficient of variation) and GCV (genotypic coefficient of variation) were calculated from the formula:

$\mathrm{PCV}=$ phenotypic standard deviation/mean; GCV = genotypic standard deviation/mean Both GCV and PCV were expressed in percentages. Genetic advance as percentage of the mean was calculated at $20 \%$ selection intensity $(\mathrm{I}=1.40)$. 


\section{RESULTS AND DISCUSSION}

No significant difference in years and rep (years) was observed for all the traits except ear length (significant rep (years)) and grain yield (significant years) (Table 4). Data for the two years were however combined for analysis due to non significance of years $\mathrm{x}$ variety interaction and homogeneity of variances for all the traits studied. Highly significant difference in variety was observed for all the flowering (days to tasselling, days to anthesis, days to silking, anthesis - silking interval) and height (plant and ear heights) traits. Similarly, differences in variety for grain yield and ear traits (ear length, kernel rows/cob and kernels/row on cob) were all highly significant.

As expected, varieties were earlier in tasselling (53.11 days) compared to anthesis (57.01 days) and silking (60.08 days) (Table 5). A wider range in the number of days to silking compared to the range in the number of days to tasselling and anthesis was observed. Mean number of days for the anthesis silking interval (ASI) was 2.67 days with a range of 0.00 to 8.00 days. Genetic variance was smaller compared to phenotypic variance for all the flowering traits. The trend in the genotypic and phenotypic coefficients of variation (GCV and PCV) and genetic advance as a percentage of the mean (GA) was similar for all the flowering traits except the ASI which recorded very high GCV, PCV and GA of $156.18 \%, 180 \%$ and $189.02 \%$ respectively. Heritability estimate was high for all the flowering traits with days to tasselling and silking recording the least and highest values of $71.84 \%$ and $77.58 \%$ respectively.

A very wide range in plant height $(102.30 \mathrm{~cm}-$ $182.57 \mathrm{~cm}$ ) compared to a narrow range of $60.17 \mathrm{~cm}-$ $79.91 \mathrm{~cm}$ for ear height, was observed for all the varieties. Phenotypic components were higher than genotypic variance components, leading to high heritability estimates of $84.92 \%$ and $81.66 \%$ for plant and ear heights respectively. Lower GCV (6.15\%) and PCV (7.54\%) were observed for the plant height compared to a higher GCV of $10.76 \%$ and PCV of $11.91 \%$ observed for the ear height. The trend in the variance components for the ear traits (ear length, kernel rows/cob and kernels/row on cob) and grain yield is similar to that observed for the height traits. Coefficients of variation values for the ear traits and grain yield were however higher compared to that of all the other traits (flowering and height traits) except ASI. The GA for ear traits and grain yield followed the same trend as the coefficients of variation with moderate to high heritability estimates $(51.34 \%$ $71.81 \%)$.
Days to tasseling was highly correlated with days to anthesis and days to silking (Table 6). Similarly, highly significant correlation was observed between days to anthesis and days to silking and between days to silking and anthesis - silking interval. No significant correlation was observed between Days to tasseling and anthesis - silking interval. Correlations between flowering traits and height traits were generally positive with ear height being significantly correlated with days to tasseling and anthesis. Correlations between anthesis - silking interval and height traits were however, negative. All the four flowering traits were also negatively correlated with all the ear traits. Highly significant correlation was observed between the plant height and ear height. Positive, but insignificant correlations were observed between height and ear traits. Correlations among the ear traits were positive with kernel rows/cob being significantly and highly significantly correlated with ear length and kernels/row on cob respectively. All correlations involving grain yield were positive but not significant except for kernel rows/cob and kernels/row on cob. Grain yield was highly significantly correlated with kernel rows/cob and kernels/row on cob.

The generally better expression of traits (including grain yield) in the 2011 compared to the 2010 growing season was due to early planting in the second year. The insignificant genotype $\mathrm{x}$ year interaction for any of the traits studied could be attributed to the consistent relative performance of the studied genotypes across the years. The highly significant difference in varieties observed for all the traits studied is an indication of genetic diversity of the evaluated genotypes in the expression of the studied traits. The grain yield of $1.25-4.13 \mathrm{t} / \mathrm{ha}$ observed in the current study is within the range reported by Oluwaranti et al. (2008) and Bello et al. (2012) for the rain forest and southern Guinea Savanna ecologies of Nigeria respectively. The higher genotypic variance compared to the error and the genotype $\mathrm{x}$ environment components of variance, is an indication that differences in the performance of the evaluated genotypes is mainly genetic. Hence the high heritability observed for almost all the traits studied. This observation is consistent with previous findings (Saleh et al., 2002) and will enhance progress in selection.

The very high GCV estimate that resulted in high PCV and GA observed for the anthesis - silking interval had been previously observed (Urrea Gomez et al., 1996) in maize evaluated on acid soils and attributed to spatial variability. 
The highly significant positive correlation among the flowering traits is an indication that the flowering traits are under the same genetic control and that they could be simultaneously used to select for early or late maturity. The negative but not significant correlation observed between the flowering and the ear traits despite the positive correlation between the two group of traits and grain yield is an indication of the need for an in-depth study in the relationship among the traits of flowering, ear and grain yield. The highly significant correlation between the two ear traits of kernels per row on cob and kernel rows/cob and between the grain yield and these two ear traits is an indication that all the three traits are under the same genetic control. The ear traits of kernels per row on cob and kernel rows/cob recorded the highest correlation and consequently contributed most to grain yield. This is a very good development in green maize production since the price of boiled and roasted corn is a function of grain filling on the cob which is dependent on the number of kernels per row on cob and kernel rows/cob.

In Nigeria, it is the field corn that is substituted for sweet corn and selecting for kernels per row on cob and kernel rows/cob in field corn will enhance its utility as green maize. The highest genetic advance of $22-49 \%$ ) observed for kernels per row on cob, kernel rows/cob and grain yield at $20 \%$ selection intensity indicates that concentrating on these three traits in selection programme will achieve a fast progress in selection. Thus grain yield could be simultaneously selected with kernels per row on cob and kernel rows/cob for improvement in dry and green maize production.

\section{ACKNOWLEDGEMENT}

The International Institute for Tropical Agriculture is hereby acknowledged for its continuous support in consistently making available improved seeds for this and other research works at the Federal University of Agriculture, Makurdi, Nigeria.

\section{REFERENCES}

1) Abdulrahman AA and Kolawole OM (2006). Traditional Preparations and Uses of Maize

2) in Nigeria. Ethonobotanical leaflets 10: 219 - 227

3) Akinwale RO, Badu-Apraku B and Fakorede MAB (2013).

Evaluation of striga-resistant early maize hybrids and test locations under striga-infested and striga-free environments. African Crop Science Journal 21(1): 1 - 19

4) Allard RW 1960. Principles of Plant Breeding. $1^{\text {st }}$ Edition. John Willey and sons Inc., New York. Pp. 485

5) Bello OB, Azeez MA, Mahmud J, Afolabi MS, Ige SA and Abdulmaliq SY (2012). Evaluation of grain yield and agronomic characteristics in drought-tolerant maize varieties belonging to two maturing groups. Journal of Agricultural Science 2(4), 70-74.

6) Bliss FA, Baker LN, Franckowiak JD, Half TC (1973). Genetic and environmental variation of seed yield: Yield Components and Seed protein quantity and quality cowpea. Crop Science 13: 656-660

7) Chen J., Xu W., Velten J., Xin Z., and Stout J. (2012). Characterization of maize inbred lines for drought and heat tolerance. Journal of Soil and Water Conservation 67 (5): $354-364$.

8) Fajemisin JM (2014). The Revolutionary Trend of Maize in Nigeria: My Memoirs. $1^{\text {st }}$ Edition. Phaloray Book Works, Nigeria. $176 \mathrm{Pp}$

9) Fehr WR 1987. Principle of Cultivars Development Macmillan publishing company. A division of Macmillan Inc. New York. Pp.1: $1-465$.

10) Keskin B, Yilmaz IH, Arvas O (2005). Determination of some yield characters of grain corn in eastern Anatolia region of Turkey. Journal of Agronomy. 4(1):14-17.

11) Obi, I. U. (1991). Maize, Its Agronomy, Diseases, Pest and Food Values. Optimal computer solutions 1td, Nigeria. 206 pp.

12) Oluwaranti A, Fakorede MAB and Badu-Apraku B. (2008) Grain yield of maize varieties of different maturity groups under marginal rainfall conditions. Journal of Agricultural Sciences 53(3): 183 - 199

13) Saleh GB, Alawi SAS and Panjaitan K. (2002). Performance, correlation and heritability studies on selected sweet corn synthetic populations. Pakistan Journal of Biological Sciences 5(3): $251-254$

14) Urrea-Gomez R, Ceballos H, Pandey S, Bahia-Filho AFC, Leon LA, 1996. A greenhouse screening technique for acid soil tolerance in maize. Agronomy Journal 88: 806 - 812

15) Wattoo F. M., Saleem M., Ahsan M., Sajjad M. and Ali W. (2009). Genetic Analysis for Yield Potential and Quality Traits in Maize (Zea mays L.). American-Eurasian Journal of Agricultural and Environmental Sciences 6(6): 723-729,. 
Genetic Variation and Relationship among Grain Yield and Yield Component Traits for Simultaneous Selection in Dry and Green Maize

Table 1: Meteorological data of Makurdi in 2010 and 2011

\begin{tabular}{|c|c|c|c|c|c|c|c|}
\hline Year & Month & $\begin{array}{l}\text { No. of } \\
\text { rainy } \\
\text { days }\end{array}$ & $\begin{array}{l}\text { Total } \\
\text { rainfall } \\
(\mathrm{mm})\end{array}$ & $\begin{array}{l}\text { Av. } \quad \text { Max } \\
\text { Temp. }\left({ }^{0} \mathrm{C}\right)\end{array}$ & $\begin{array}{l}\text { Av. } \\
\text { Temp. }\left({ }^{0} \mathrm{C}\right)\end{array}$ & $\begin{array}{l}\text { Av. Max Relative } \\
\text { Humidity }(\%)\end{array}$ & $\begin{array}{l}\text { Av. Min. } \\
\text { Relative } \\
\text { Humidity } \\
(\%)\end{array}$ \\
\hline \multirow[t]{6}{*}{2010} & July & 16 & 245.3 & 31.2 & 21.2 & $77.0^{*}$ & \\
\hline & August & 15 & 198.5 & 30.2 & 22.1 & $77.4^{*}$ & \\
\hline & September & 10 & 190.2 & 31.4 & 21.2 & $77.8^{*}$ & \\
\hline & October & 8 & 113.3 & 32.4 & 23.3 & $75.2^{*}$ & \\
\hline & November & - & - & 33.4 & 21.2 & $62.0^{*}$ & \\
\hline & December & & & & & & \\
\hline \multirow[t]{12}{*}{2011} & January & - & - & 34.3 & 16.5 & 49 & 28 \\
\hline & February & 3 & 66.8 & 35.3 & 24.4 & 74 & 44 \\
\hline & March & - & - & 37.0 & 26.2 & 68 & 37 \\
\hline & April & 7 & 78.0 & 35.3 & 25.0 & 76 & 45 \\
\hline & May & 7 & 142.8 & 33.0 & 24.0 & 80 & 46 \\
\hline & June & 6 & 60.4 & 31.1 & 22.6 & 78 & 46 \\
\hline & July & 12 & 87.0 & 30.7 & 22.0 & 79 & 45 \\
\hline & August & 14 & 217.4 & 29.5 & 22.4 & 82 & 64 \\
\hline & September & 10 & 272.0 & 30.3 & 21.9 & 83 & 66 \\
\hline & October & 18 & 293.4 & 30.8 & 21.6 & 84 & 70 \\
\hline & November & - & - & 34.0 & 19.4 & 75 & 52 \\
\hline & December & - & - & 34.5 & 14.5 & 50 & 28 \\
\hline
\end{tabular}

*= average monthly relative humidity. Source: Meteorological Station, Tactical Air Command, Air Force Base, Makurdi. 
Genetic Variation and Relationship among Grain Yield and Yield Component Traits for Simultaneous Selection in Dry and Green Maize

Table 2: Physical and chemical characteristics of the soils used for the experiment during the 2010 and 2011 cropping season

\begin{tabular}{|l|l|l|}
\hline Soil characteristics & $\mathbf{2 0 1 0}$ & $\mathbf{2 0 1 1}$ \\
\hline Sand $(\%)$ & 87.10 & 89.00 \\
\hline Silt $(\%)$ & 84.00 & 79.00 \\
\hline Clay $(\%)$ & 4.20 & 4.30 \\
\hline Textural Class & Sandy Loam & Sandy Loam \\
\hline $\mathrm{PH}\left(\mathrm{H}_{2} \mathrm{O}\right)$ & 6.42 & 6.35 \\
\hline $\mathrm{PH}(\mathrm{KCl})$ & 5.01 & 5.10 \\
\hline Organic Matter $(\%)$ & 1.66 & 1.69 \\
\hline Organic Carbon $(\%)$ & 0.96 & 0.98 \\
\hline Total Nitrogen $\left(\mathrm{gkg}^{-1}\right)$ & 2.75 & 2.70 \\
\hline Available P $\left.(\mathrm{mgkg})^{-1}\right)$ & 5.50 & 4.60 \\
\hline Exchangeable Ca $\left(\mathrm{cmolkg}^{-1}\right)$ & 3.30 & 3.10 \\
\hline Exchangeable K $\left(\mathrm{cmolkg}^{-1}\right)$ & 0.31 & 0.29 \\
\hline Exchangeable $\mathrm{Mg}\left(\mathrm{cmolkg}^{-1}\right)$ & 0.91 & 0.97 \\
\hline Exchangeable Na $\left(\mathrm{cmolkg}^{-1}\right)$ & 0.16 & 0.15 \\
\hline Exchangeable Acidity & 2.30 & 2.23 \\
\hline CEC $\left(\mathrm{cmolkg}{ }^{-1}\right)$ & 2.30 & 2.20 \\
\hline
\end{tabular}

Table 3: Name/code, germplasm type and source of germplasm

\section{NAME/CODE GERMPLASM TYPE SOURCE OF GERMPLASM}

OBA 98

Hybrid

LNTPXLNP-WC $_{3} \quad$ OPV

TZBR ELD. $3 \mathrm{C}_{3}$

OPV

AMA. TZBR-W

OPV

DT. SR -WC

OPV

TZE COMP.DT.C 2

OPV

ACr94TZE COMP.5-W

OPV

EV99 DT-W STR

OPV

BR9928DMRSR

OPV

99 TZEE-Y STR

OPV

2000 SYNEE-W STR

OPV

Local (a)

OPV

Local (b)

OPV

Local (c)

OPV

Local (d)

OPV
IITA (Nigeria)

IITA (Nigeria)

IITA (Nigeria)

IITA (Nigeria)

IITA (Nigeria)

IITA (Nigeria)

IITA (Nigeria)

IITA (Nigeria)

IITA (Nigeria)

IITA (Nigeria)

IITA (Nigeria)

Benue State

Benue State

Kogi State

Kogi State 
Genetic Variation and Relationship among Grain Yield and Yield Component Traits for Simultaneous Selection in Dry and Green Maize

Table 4: mean squares for grain yield and yield components of elite hybrids and open pollinated varieties of maize evaluated in Makurdi (southern Guinea savanna), Nigeria

\begin{tabular}{|c|c|c|c|c|c|c|c|c|c|c|c|}
\hline $\begin{array}{l}\text { Source of } \\
\text { variation }\end{array}$ & df & $\begin{array}{l}\text { Days to } \\
\text { tasselin } \\
\text { g }\end{array}$ & $\begin{array}{l}\text { Days to } \\
\text { anthesis }\end{array}$ & $\begin{array}{l}\text { Days to } \\
\text { silking }\end{array}$ & $\begin{array}{l}\text { Anthesis- } \\
\text { silking } \\
\text { interval }\end{array}$ & $\begin{array}{l}\text { Plant } \\
\text { height }\end{array}$ & $\begin{array}{l}\text { Ear } \\
\text { height }\end{array}$ & $\begin{array}{l}\text { Ear } \\
\text { length }\end{array}$ & $\begin{array}{l}\text { Kernel } \\
\text { rows/cob }\end{array}$ & $\begin{array}{l}\text { Kernels } \\
\text { /row on } \\
\text { cob }\end{array}$ & $\begin{array}{l}\text { Grai } \\
\text { n } \\
\text { yield }\end{array}$ \\
\hline Years & 1 & 12.06 & 9.65 & 11.91 & 4.95 & 17.61 & 11.13 & 4.85 & 8.17 & 15.65 & $1.16^{*}$ \\
\hline Rep (years) & 4 & 6.25 & 4.26 & 7.14 & 3.01 & 8.17 & 6.21 & $0.95^{*}$ & 4.34 & 6.91 & 0.41 \\
\hline Entries & 14 & $30.14^{* *}$ & $42.11^{* *}$ & $45.48^{* *}$ & $17.98^{* *}$ & $\begin{array}{l}86.19^{*} \\
*\end{array}$ & $54.36^{*}$ & $10.21^{*}$ & $8.90^{* *}$ & $48.10^{* *}$ & $1.38^{*}$ \\
\hline $\begin{array}{ll}\text { Years } & x \\
\text { entry }\end{array}$ & 14 & 5.22 & 4.41 & 6.35 & 1.17 & 3.18 & 4.34 & 3.11 & 3.96 & 8.16 & 0.31 \\
\hline Error & 56 & 6.69 & 8.54 & 8.33 & 5.65 & 14.21 & 8.62 & 2.86 & 3.12 & 10.95 & 0.29 \\
\hline
\end{tabular}

Table 5: Means, range, variance components, coefficients of variation, heritability and genetic advance for grain yield and yield components of elite hybrids and open pollinated varieties of maize evaluated in Makurdi (southern Guinea savanna), Nigeria

\begin{tabular}{|c|c|c|c|c|c|c|c|c|c|c|}
\hline Trait & Mean & Range & $\delta^{2} \mathrm{~g}$ & $\delta^{2}{ }_{\text {ge }}$ & $\delta^{2}{ }_{e}$ & $\delta_{\text {ph }}^{2}$ & $\begin{array}{l}\text { GCV } \\
(\%)\end{array}$ & $\begin{array}{l}\text { PCV } \\
(\%)\end{array}$ & $\begin{array}{l}\mathrm{H}_{\mathrm{BS}} \\
(\%)\end{array}$ & $\begin{array}{l}\text { GA } \\
(\%)\end{array}$ \\
\hline Days to tasseling & 53.11 & $42.67-64.00$ & 27.53 & 4.10 & 6.69 & 38.32 & 9.88 & 11.66 & 71.84 & 11.72 \\
\hline Days to anthesis & 57.01 & $46.33-68.12$ & 39.90 & 2.99 & 8.54 & 51.43 & 11.08 & 12.58 & 77.58 & 13.66 \\
\hline Days to silking & 60.08 & $46.67-76.12$ & 42.30 & 4.96 & 8.33 & 55.59 & 10.83 & 12.41 & 76.09 & 13.22 \\
\hline Anthesis-silking interval & 2.67 & $0.00-8.00$ & 17.39 & 0.23 & 5.65 & 23.27 & 156.18 & 180.67 & 74.73 & 189.02 \\
\hline Plant height & 132.30 & $\begin{array}{l}102.30 \\
182.57\end{array}$ & 84.60 & 0.81 & 14.21 & 99.62 & 6.95 & 7.54 & 84.92 & 8.97 \\
\hline Ear height & 67.14 & $60.17-79.91$ & 52.19 & 2.90 & 8.62 & 63.91 & 10.76 & 11.91 & 81.66 & 13.61 \\
\hline Ear length & 17.74 & $13.78-24.13$ & 8.65 & 2.63 & 2.86 & 14.14 & 16.58 & 21.20 & 61.17 & 18.15 \\
\hline Kernel rows/cob & 11.62 & $9.67-15.80$ & 6.92 & 3.44 & 3.12 & 13.48 & 22.64 & 31.60 & 51.34 & 22.71 \\
\hline Kernels/row on cob & 24.16 & $16.33-34.27$ & 44.02 & 6.33 & 10.95 & 61.30 & 27.46 & 32.41 & 71.81 & 32.58 \\
\hline Grain yield & 2.58 & $1.25-4.13$ & 1.22 & 0.26 & 0.29 & 1.77 & 42.81 & 51.57 & 68.93 & 49.76 \\
\hline
\end{tabular}


Genetic Variation and Relationship among Grain Yield and Yield Component Traits for Simultaneous Selection in Dry and Green Maize

Table 6: Phenotypic correlation among character means for grain yield and yield components of maize evaluated in Makurdi (southern Guinea savanna), Nigeria

\begin{tabular}{|c|c|c|c|c|c|c|c|c|c|}
\hline & $\begin{array}{l}\text { Days to } \\
\text { anthesi } \\
\text { s }\end{array}$ & $\begin{array}{l}\text { Days } \\
\text { to } \\
\text { Silkin } \\
\text { g }\end{array}$ & $\begin{array}{l}\text { Anthesis } \\
\text {-Silking } \\
\text { Interval }\end{array}$ & $\begin{array}{l}\text { Plant } \\
\text { Heigh } \\
\text { t }\end{array}$ & $\begin{array}{l}\text { Ear } \\
\text { Heigh } \\
\text { t }\end{array}$ & $\begin{array}{l}\text { Ear } \\
\text { Lengt } \\
\text { h }\end{array}$ & $\begin{array}{l}\text { Kernels/Ro } \\
\text { w on Cob }\end{array}$ & $\begin{array}{l}\text { Kernel } \\
\text { Rows/Co } \\
\text { b }\end{array}$ & $\begin{array}{l}\text { Grain } \\
\text { Yield }\end{array}$ \\
\hline $\begin{array}{ll}\text { Days } & \text { to } \\
\text { tasseling }\end{array}$ & $0.97^{* *}$ & $0.90^{* *}$ & 0.44 & 0.44 & $0.52^{*}$ & -0.22 & -0.08 & -0.29 & 0.12 \\
\hline $\begin{array}{ll}\text { Days to } \\
\text { anthesis }\end{array}$ & & $0.96^{* *}$ & $0.53^{*}$ & 0.41 & $0.49^{*}$ & -0.30 & -0.13 & -0.36 & 0.04 \\
\hline $\begin{array}{ll}\text { Days } & \text { to } \\
\text { silking } & \end{array}$ & & & $0.76^{* *}$ & 0.30 & 0.37 & -0.40 & -0.12 & -0.38 & 0.09 \\
\hline $\begin{array}{l}\text { Anthesis- } \\
\text { silking } \\
\text { interval }\end{array}$ & & & & -0.05 & -0.01 & -0.49 & -0.04 & -0.29 & 0.17 \\
\hline $\begin{array}{l}\text { Plant } \\
\text { height }\end{array}$ & & & & & $0.95^{* *}$ & 0.36 & 0.18 & 0.04 & 0.09 \\
\hline Ear height & & & & & & 0.37 & 0.18 & 0.04 & 0.09 \\
\hline Ear length & & & & & & & 0.43 & $0.54^{*}$ & 0.20 \\
\hline $\begin{array}{l}\text { Kernel } \\
\text { rows/cob }\end{array}$ & & & & & & & & $0.91^{* *}$ & $0.83^{* * *}$ \\
\hline $\begin{array}{l}\text { Kernels/ro } \\
\text { w on cob }\end{array}$ & & & & & & & & & $\begin{array}{l}\mathbf{0 . 7 4 *} \\
* \\
\end{array}$ \\
\hline
\end{tabular}

